\title{
The Implication of AMPA Receptor in Synaptic Plasticity Impairment and Intellectual Disability in Fragile X Syndrome
}

\author{
Gui-Rong CHENG ${ }^{1,2 \#}$, Xiang-Yu LI ${ }^{1,2 \#}$, Ya-Die XIANG ${ }^{1,2 \#}$, Dan LIU ${ }^{1,2}$, \\ Shawn M. MCCLINTOCK ${ }^{1,2,3,4}$, Yan ZENG ${ }^{1,2}$ \\ "These authors contributed equally to this work as first authors.
}

${ }^{1}$ Brain and Cognition Research Institute, Wuhan University of Science and Technology, Wuhan, China, ${ }^{2}$ Hubei Key Laboratory of Hazard Identification and Control for Occupational Disease, Wuhan, China, ${ }^{3}$ Department of Psychiatry, University of Texas Southwestern Medical Center, Dallas, TX, USA, ${ }^{4}$ Department of Psychiatry and Behavioral Sciences, Duke University School of Medicine, Durham, NC, USA

Received August 27, 2016

Accepted February 21, 2017

On-line July 18, 2017

\begin{abstract}
Summary
Fragile $X$ syndrome (FXS) is the most frequently inherited form of intellectual disability and prevalent single-gene cause of autism. A priority of FXS research is to determine the molecular mechanisms underlying the cognitive and social functioning impairments in humans and the FXS mouse model. Glutamate ionotropic alpha-amino-3-hydroxy-5-methyl-4-isoxazole propionic acid (AMPA) receptors (AMPARs) mediate a majority of fast excitatory neurotransmission in the central nervous system and are critically important for nearly all aspects of brain function, including neuronal development, synaptic plasticity, and learning and memory. Both preclinical and clinical studies have indicated that expression, trafficking, and functions of AMPARs are altered and result in altered synapse development and plasticity, cognitive impairment, and poor mental health in FXS. In this review, we discuss the contribution of AMPARs to disorders of FXS by highlighting recent research advances with a specific focus on change in AMPARs expression, trafficking, and dependent synaptic plasticity. Since changes in synaptic strength underlie the basis of learning, development, and disease, we suggest that the current knowledge base of AMPARs has reached a unique point to permit a comprehensive re-evaluation of their roles in FXS.
\end{abstract}

\section{Key words}

Fragile X syndrome - Intellectual disability - AMPA receptors • Synaptic plasticity $\bullet$ Learning and memory

\section{Corresponding author}

Y. Zeng, Brain and Cognition Research Institute, School of Medicine, Wuhan University of Science and Technology, Wuhan, China and Hubei Key Laboratory of Hazard Identification and Control for Occupational Disease, Wuhan, China. Fax: 86-27-84668879. E-mail: yanzeng11@yahoo.com

\section{Introduction}

Fragile X syndrome (FXS) is one of the most common forms of intellectual disability and monogenic cause of autism spectrum disorders (ASD) (Harris et al. 2008, Rogers et al. 2001). In most cases, this disorder results from the transcriptional silencing of the fragile $X$ mental retardation $1(f m r l)$ gene on chromosome $\mathrm{Xq}$ 27.3, due to an excessive expansion of a CGG repeat found in the 5'-untranslated region (O'Donnell et al. 2002, Bagni et al. 2005, Santoro et al. 2012). The fmrl gene product, fragile $\mathrm{X}$ mental retardation protein (FMRP), a selective RNA-binding protein is absent in FXS (Antar et al. 2006, Bassell et al. 2008, Till et al. 2012). FMRP modulates expression of nearly a third of 
pre- and post-synaptic proteomes (Liao et al. 2008, Darnell et al. 2011, Klemmer et al. 2011) and functions at both pre- and post-synaptic compartments (Till et al. 2010, Deng et al. 2013, Patel et al. 2013). In its absence, the transcripts are over translated in the dendrites and axons, which are typically regulated by FMRP (Bassell et al. 2008, Waung et al. 2009, Dierssen et al. 2006). In particular, one of the primary defects associated with the absence of FMRP appears to be excessive synaptic alphaamino-3-hydroxy-5-methyl-4-isoxazole propionic acid (AMPA) receptors (AMPARs) internalization in response to the signaling of metabotropic glutamate receptors (mGluR) (O'Donnell et al. 2002, Nakamoto et al. 2007, Bear et al. 2004, Huber et al. 2002). Therefore, FXS is partially a result of exaggerated internalization of synaptic AMPARs.

Since AMPARs are important for neuronal development, synaptic plasticity, and cognitive function (e.g. learning and memory) (Hamad et al. 2011, Urbanska et al. 2008, Malenka et al. 2003), the effects of FMRP on complex pathways that control AMPARs insertion and removal from the synaptic membrane could have a large effect on synaptic strength and excitability. In this review, we discuss the specific contribution of AMPARs to FXS disorders by their effect on multiple levels and highlight how defects in AMPAR expression and trafficking are important to fragile $\mathrm{X}$ intellectual disability. We suggest that the knowledge base of AMPARs has reached a unique point to permit a comprehensive re-evaluation of their role in FXS.

We performed a desk review of journal publications on FXS and AMPAR, and implemented a comprehensive search strategy for different categories using a combination of text words and indexing terms (MeSH) in PubMed, China National Knowledge Infrastructure, Wanfang databases over the last three decades (1986 - 2016). To obtain the information relevant to fragile mental retardation protein or $f m r l$ and AMPAR and glutamate, we used the keywords "fragile $\mathrm{X}$ syndrome" or "fragile mental retardation protein" or "fmrl" or "neurodevelopmental disorders" and "AMPAR" or "Glutamate" or "mGluR1" or "mGluR5." We included only those publications written in English language and excluded book reviews, editorials, errata, conference proceeding overviews, and abstracts.

\section{Genetic basis and cognitive disability in FXS}

Fragile X syndrome was discovered in association with the fragile site of the $\mathrm{X}$ chromosome in two brothers in 1969 by Lubs and colleagues (Lubs et al. 1969). In 1991, the gene responsible for FXS, fmrl, was identified and scientists developed a specific associated DNA test (Verkerk et al. 2008, Oberle et al. 1991, Davids et al. 1990). The normal allele of the fmrl gene typically has 5 to 40 CGG repeats in the 5 ' untranslated region. The abnormal alleles of dynamic mutations (Fig. 1) include the full mutation ( $>200 \mathrm{CGG}$ repeats), premutation (55-200 CGG repeats), and the gray zone mutation (45-54 CGG repeats) (Sutcliffe et al. 1992). Full mutation alleles are associated with intellectual disability and behavioral impairments (e.g. impaired social interaction and communication) (Verkerk et al. 2008, Oberle et al. 1991, Fu et al. 1991). Carriers of premutation alleles are at risk for adult-onset neurodegenerative disorder known as fragile $\mathrm{X}$-associated tremor/ataxia syndrome (Hagerman et al. 2013), and female carriers are at risk for fragile $\mathrm{X}$-associated primary ovarian insufficiency. The latter condition is associated with fertility problems and an earlier than normal menopause (Sullivan et al. 2011, Sherman et al. 2014).

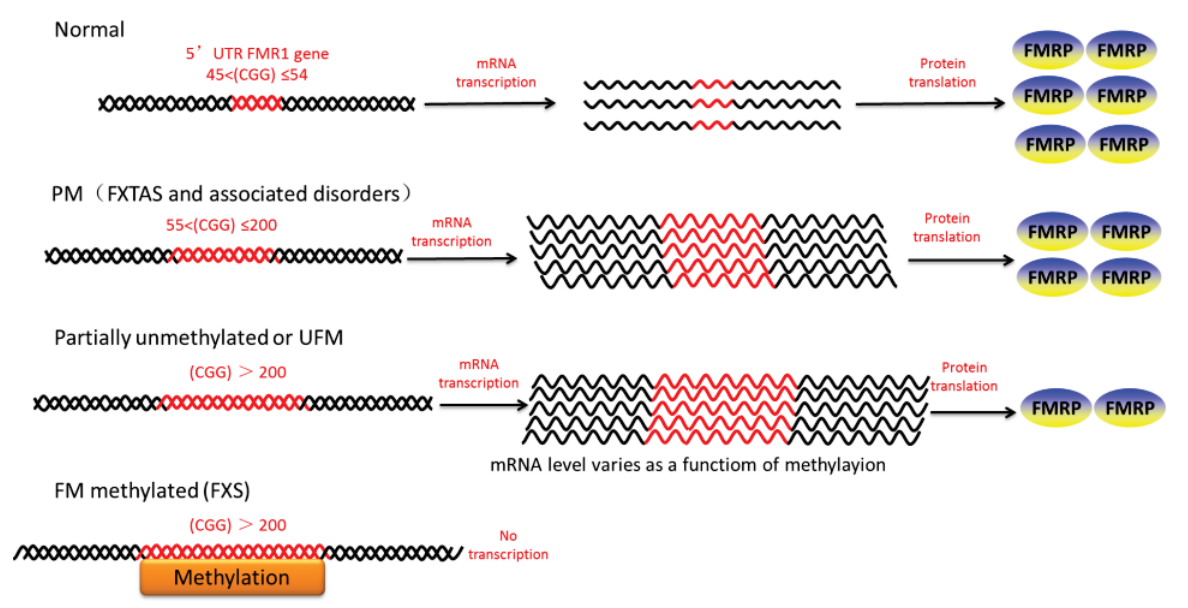

Fig. 1. The abnormal alleles of dynamic mutations include the full mutation (>200 CGG repeats), premutation (55-200 CGG repeats) and the gray zone mutation (45-54 CGG repeats). 
Patients with FXS typically have a significant learning disability with an intellectual quotient (IQ) that declines from about 80 at 5 years of age to about 50 through the pubertal years (Skinner et al. 2005, Loesch et al. 2004). Cognitive difficulties include impaired working and short-term memory, executive function, arithmetic, and visuospatial abilities (Kemper et al. 1988). Mental health symptoms in patients with FXS include anxiety, depression, hyperactivity, impulsivity, and aggression (Tsiouris et al. 2004). Because the disorder is X-linked, women are generally less affected than men, particularly with regard to cognitive abilities. However, women tend to have greater risk for mental health problems relative to the general population (De Vries et al. 1996, Freund et al. 1993).

\section{AMPARs expression in developmental phases of FXS}

Functional AMPARs are expressed throughout the brain in various tetrameric assemblies of GluA1, GluA2, GluA3, and GluA4 (Beneyto et al. 2004) (Fig. 2), and play a prominent role in neuronal development. During the neonatal developmental period, some synapses are named as silent synapses due to the lack of AMPARs at their resting state and instead only contain NMDARs (Nicoll et al. 1997, Liao et al. 1995). From a functional standpoint, synapses of this nature are rendered "silent" to glutamate release since NMDARs are tonically blocked by $\mathrm{Mg}^{2+}$ at resting membrane potentials. The proportion of AMPAR-deficient synapses is greater in the neonatal central nervous system (CNS) than in the adult (Wu et al. 1997, Petralia et al. 1999, Xiao et al. 2004), and the subunit composition and relative abundance of AMPA and NMDA receptors are adjusted as crucial steps in the establishment of a functionally mature synapse (Bellone et al. 2007). However, the loss of FMRP leads to a substantial decrease in the AMPA/NMDA ratio between postnatal days 4 (P4) and P7, with the lowest AMPA/NMDA ratio occurring just before closure of the normal critical period (Harlow et al. 2010). Therefore, the number of silent synapses is increased in the critical period in fmrl KO neurons. In WT mice, most of these silent synapses are unsilenced due to the increased AMPAR subunits expression in the cell membrane during the later developmental period, but one study found increased silent synapses that persisted later in development with a temporal delay in the window for synaptic plasticity in fmrl KO mice (Harlow et al. 2010). In another fmrl KO2 mouse model, there was also a significantly lower AMPA/NMDA ratio compared with WT mice at P14, but not at 6 or 7 weeks (Pilpel et al. 2009). This new fmr 1 $\mathrm{KO} 2$ line is a more versatile fmrl in vivo $\mathrm{KO}$ model by flanking the promoter and first exon of fmrl with lox $\mathrm{P}$ sites. The new line expresses no FMRP and lacks detectable fmrl transcripts (Mientjes et al. 2006, Oostra et al. 1994). Therefore, the lower AMPA/ NMDA ratio in fmrl $\mathrm{KO} 2$ mice is the direct result of the absence of FMRP and $f m r l$ transcripts. This difference in the AMPA/NMDA ratio at $\mathrm{P} 14$ is probably related to an up-regulation of the NMDA receptor component concurrent with a down-regulation of the AMPAR component (Pilpel et al. 2009). In line with up-regulation of the NMDA component, the induction of NMDA receptor-dependent LTP following a low-frequency pairing protocol is increased in $f m r 1 \mathrm{KO} 2$ mice only at this developmental stage (Pilpel et al. 2009). Taken together, the expression of AMPARs in various brain regions is decreased during postnatal development in fmrl KO mice (Neves et al. 2008, Davidkova et al. 2007, Jin et al. 2004).

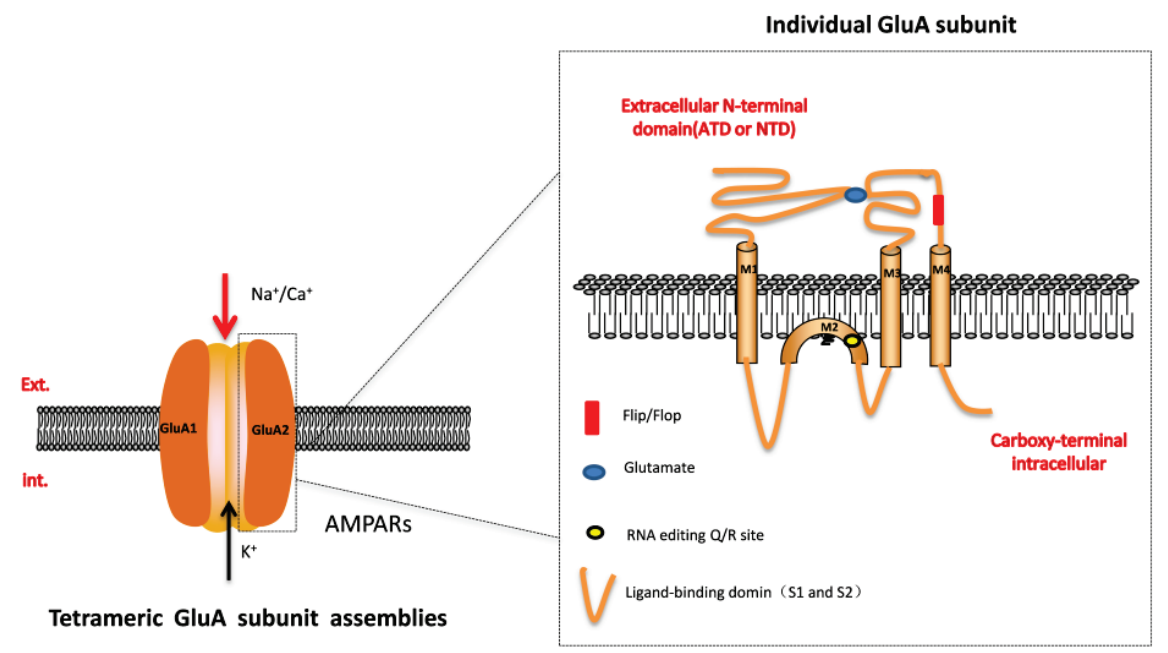

Fig. 2. AMPA receptors (AMPARs) are heteromeric assemblies of four core subunits, GluA1, GluA2, GluA3, and GluA4. They mediate most fast excitatory neurotransmission. The different combinations are not completely variable. In CA1 neurons, for instance, mostly express GluA1/GluA2 and GluA2/GluA3 are heteromers, while a smaller proportion of GluA1/GluA1 are homomers. GluA2/GluA2 and GluA3/GluA3 can't be formed. 
The alteration of AMPARs expression in FXS animal model

There are multiple important processes involved in AMPARs expression and their synaptic function including protein synthesis, proteasomal degradation, alternative splicing, and mRNA trafficking. A component in the regulation of AMPAR subunits and associated protein complex synthesis is FMRP, which is localized to dendritic spines (Feng et al. 1997) and traffics within dendrites and at the synapses after stimulation (Antar et al. 2004, Muddashetty et al. 2007) (Fig. 3).

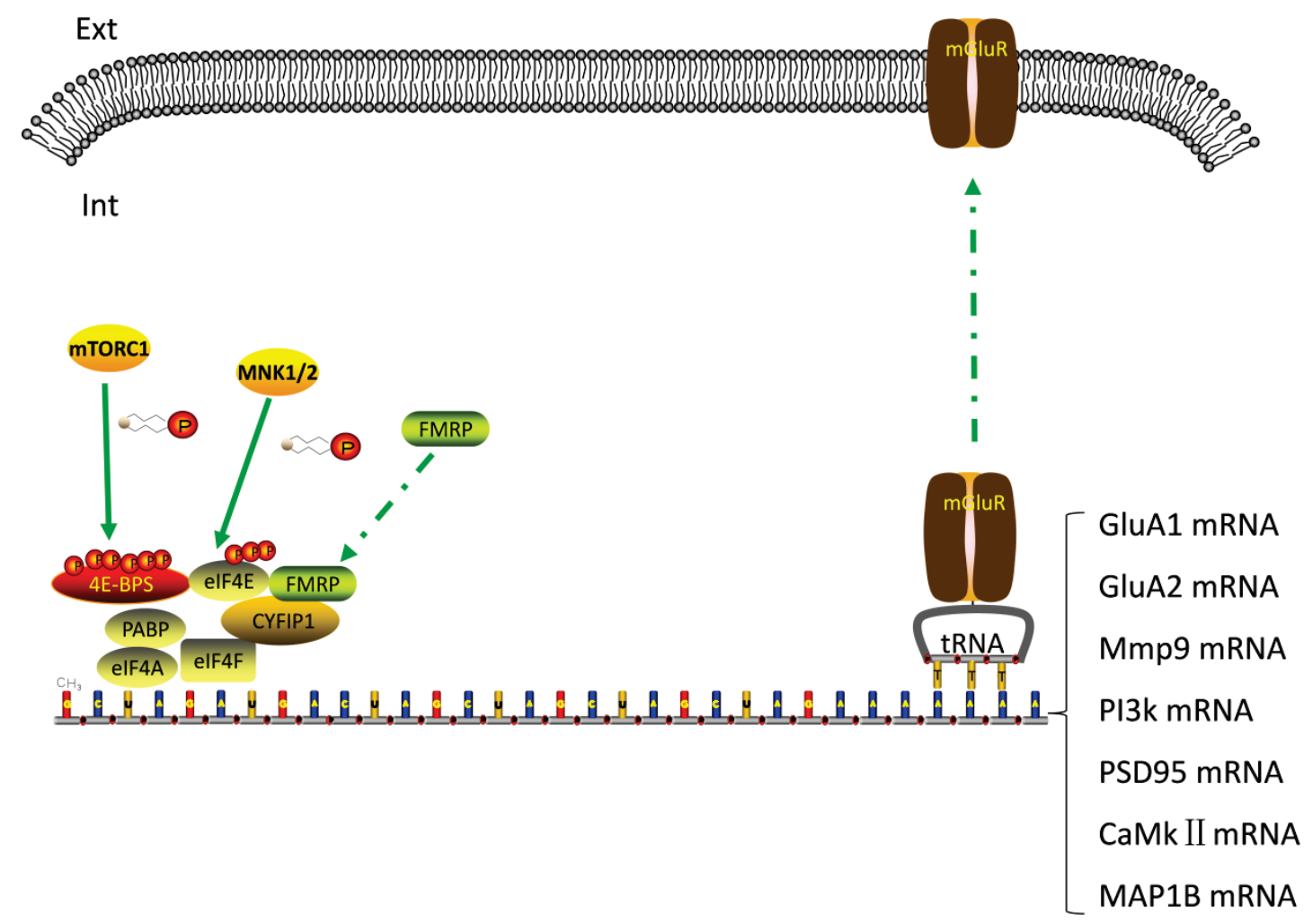

Fig. 3. The possible targets of FMRP in dendritic spines. FMRP is a RNA binding protein that transports, stabilizes, and regulates the translation of hundreds of mRNAs at the synapse. It has been suggested that it plays a role in regulation of the local synthesis of AMPAR subunits and associated protein complexes, including MMP 9, PI3K, PSD95, CaMKII and MAP1B. The symbols used in the Figure 3 are listed below: Ext=extracellular space; Int=intracellular space; $\mathrm{mTOR}=$ mammalian target of rapamycin complex 1 or mechanistic target of rapamycin complex 1; Mnk1/2=MAPK-interacting kinase 1 and 2 (Mnk1/2); eIF4=eukaryotic translation initiation factor 4E; EIF4EBP1Eukaryotic translation initiation factor 4E-binding protein 1; $\mathrm{PABP}=$ Poly (A)-binding protein; CYFIP1=Cytoplasmic FMR1-interacting protein 1; mGluRs=metabotropic glutamate receptors; PI3Ks=phosphatidylinositol-3-kinases; MMP-9=Matrix metallopeptidase 9; PSD-95=postsynaptic density protein 95; CaMKII $=\mathrm{Ca}^{2+} / \mathrm{calmodulin}^{-d e p e n d e n t}$ protein kinase II; $\mathrm{MAP1B}=$ Microtubule-associated protein $1 \mathrm{~B}$.

Multiple preclinical and primary neuron studies have suggested that the local synthesis AMPAR subunits are dysregulated in fmrl KO mice (Bear et al. 2004, Huber et al. 2002, Muddashetty et al. 2007, Soden et al. 2010, Garber et al. 2008). Indeed, in fmrl KO mice, GluA1 is decreased in the cortical synapses (Li et al. 2002), hippocampal neurons (Grossman et al. 2010), and synapse membrane (Nakamoto et al. 2007, Guo et al. 2015, Hu et al. 2008). The FXS mGluR theory posits that FMRP loss within the mGluR signaling pathway leads to several downstream consequences of mGluR activation and increased internalization of AMPAR subunits (Nakamoto et al. 2007, Huber et al. 2007, Chuang et al.
2005). The role of FMRP in excessive mGluR-dependent internalization of AMPARs has been demonstrated in normal rat neuronal hippocampal cultures using FMRP siRNA (Nakamoto et al. 2007). Similarly, the internalization of surface GluA1 is impaired in fmrl KO prefrontal cortex (PFC) and amygdala neurons (Wang et al. 2010, Suvrathan et al. 2010). The changes in AMPAR subunit expression are also involved in alterations in AMPAR mRNAs trafficking. Interestingly, while their mRNA levels remain unchanged in $f m r l$ KO mice, their subcellular localization is altered. The quantitative analysis of mRNA levels in FMRP-specific immunoprecipitations from synaptoneurosomes has 
substantiated the association of FMRP with GluA1 and GluA2 mRNAs (Muddashetty et al. 2007). In addition, studies have also linked Strial-Enriched protein Tyrosine
Phosphatase (STEP) dysregulation in fmrl KOs to aberrant endocytosis of AMPARs (Huber et al. 2002, Zhang et al. 2008) (Fig. 4).

\section{Fragile X Syndrome}

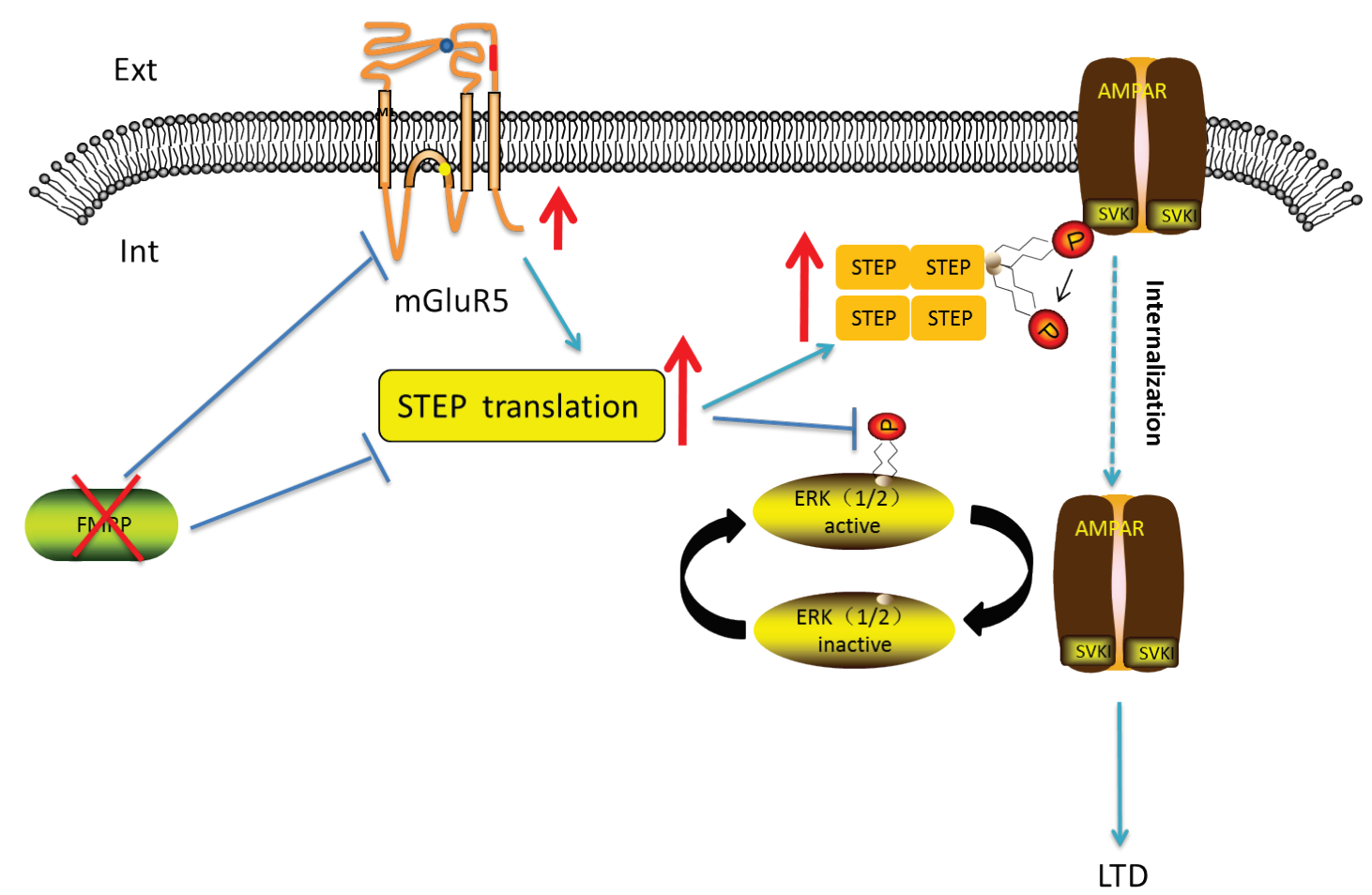

Fig. 4. The mGluR theory refer to the pathophysiology in FXS, which proposes that loss of FMRP within mGluR signaling pathway leads to excessive expression of several downstream consequences of mGluR activation, such as STEP, and increased internalization of AMPAR subunits.

Our prior work indicated that 7, 8-dihydroxyflavone (7, 8-DHF), an identified high affinity tyrosine receptor kinase B (TrkB) agonist, enhances expression of GluA1 at the synapses in fmrl KO mice (Tian et al. 2015). Potentially related to drug-induced increases in AMPAR subunits at synapses, 7, 8-DHF leads to phosphorylation of specific serine sites on subunits Ser818 and Ser813 of GluA1, and Ser880 of GluA2, as well as phosphorylation of TrkB, calcium/calmodulin-dependent protein kinase II (CaMKII), and protein kinase C (PKC) (Tian et al. 2015). Collectively, FMRP ablation results in glutamatergic signaling maturation dysregulation (Bear et al. 2004). Such AMPAR signaling dysregulation at the synapses may impair molecular composition control of the postsynaptic density and consequently alter synaptic transmission. This alteration in synaptic transmission could lead to impairment of neuronal plasticity and produce neurogenesis-associated learning deficits that have been observed in fmrl KO mice and patients with
FXS (Muddashetty et al. 2007, Wang et al. 2011, Guo et al. 2011). Some chemicals (e.g. 7,8-DHF) induce synapse expression of AMPA GluA1 through increasing phosphorylation of AMPAR subunits, which then remedies cognitive dysfunction and spine abnormalities in fmrl KO mice (Tian et al. 2015).

FMRP has two conserved autosomal paralogs, FXR1P and FXR2P (also known as FXR1 and FXR2), and all three RNA-binding proteins are enriched in neurons (Li et al. 2014, Darnell et al. 2009). Studies have shown that FMRP and its paralogs have the ability to interact with one another, and that FMRP and FXR2P double KO mice show greater neurobehavioral abnormalities (e.g. hyperactivity, exaggerated locomotor activity, contextual fear conditioning) compared to single-mutant mice (Spencer et al. 2014, Spencer et al. 2011). FXR2P reduces Noggin mRNA stability in adult neural stem cells (Guo et al. 2011) and binds to GluA1 mRNA to enhance stability and protein production (Guo et al. 2011). These results suggest a role for FMRP in the 
regulation of the local synthesis of AMPAR subunits and associated protein complexes.

\section{The alteration of AMPARs trafficking in FXS}

AMPAR trafficking is a driving process for synaptic plasticity that underlies learning and memory, and involves the dynamic processes of exocytosis, endocytosis, endosomal recycling (Pilpel et al. 2009, Wang et al. 2010, Hanley et al. 2014, Haering et al. 2014, Chater et al. 2014, Kessels et al. 2009, Perestenko et al. 2003). It is well known that FMRP has significant roles in regulating the synaptic delivery of GluA1 and AMPAR trafficking (Nakamoto et al. 2007, Hu et al. 2008) (Fig. 4). Aberrant AMPAR trafficking and consequent synaptic defects are strongly implicated in FXS (Nakamoto et al. 2007, Yan et al. 2005, McBride et al. 2005). Also, some of the defects are associated with the lack of FMRP as demonstrated in FMRP-absent Drosophila and mouse models (Yan et al. 2005, McBride et al. 2005). One alteration in AMPAR trafficking is involved in the regulation of small GTPase, Ras, and Rap signaling (Isaac et al. 2007, Gu et al. 2007), and many synaptic proteins in the NMDA receptor (NMDAR)-RasPI3K/PKB signaling interactome (Darnell et al. 2013,
Ascano et al. 2012, Kielland et al. 2009). FMRP modulates the synaptic trafficking of GluA1 through Ras (Soden et al. 2009, Lim et al. 2009). LTP is reduced by approximately $50 \%$ in $\mathrm{fmr} 1 \mathrm{KO}$ mice due to selective impairment of synaptic trafficking of GluA1 and GluA4-containing AMPARs, which results from deficient Ras activity (Hu et al. 2008). Enhancing Ras signaling restores GluA1-containing AMPARs synaptic delivery and LTP in fmrl $\mathrm{KO}$ mice ( $\mathrm{Hu}$ et al. 2008). Hence, FMRP deficiency leads to reduced membrane and synaptic delivery of AMPAR subunits and reduced AMPA current levels (Hu et al. 2008).

Many molecules interact with AMPARs and are involved in their trafficking (Joyce et al. 2010, Wang et al. 2012). Some of those molecules implicated in FXS include tumor necrosis factor alpha (TNFa) (Stellwagen et al. 2006), retinoic acid (Soden et al. 2010), PICK1 (Anggono et al. 2011), activity-regulated cytoskeletal gene and protein (Arc/Arg3.1) (Shepherd et al. 2006), and phosphatidylinositide-3 kinase (PI3K) signaling (Hou et al. 2008). In addition, proteins regulating AMPAR endocytosis such as Arc, microtubule associated protein 1B (MAP1B), STEP, amyloid precursor protein (APP) (Fig. 5), and termed LTD proteins, are upregulated in neuronal dendrites in fmrl $\mathrm{KO}$ mice and stable during mGluR-LTD.

\section{Fragile X Syndrome}

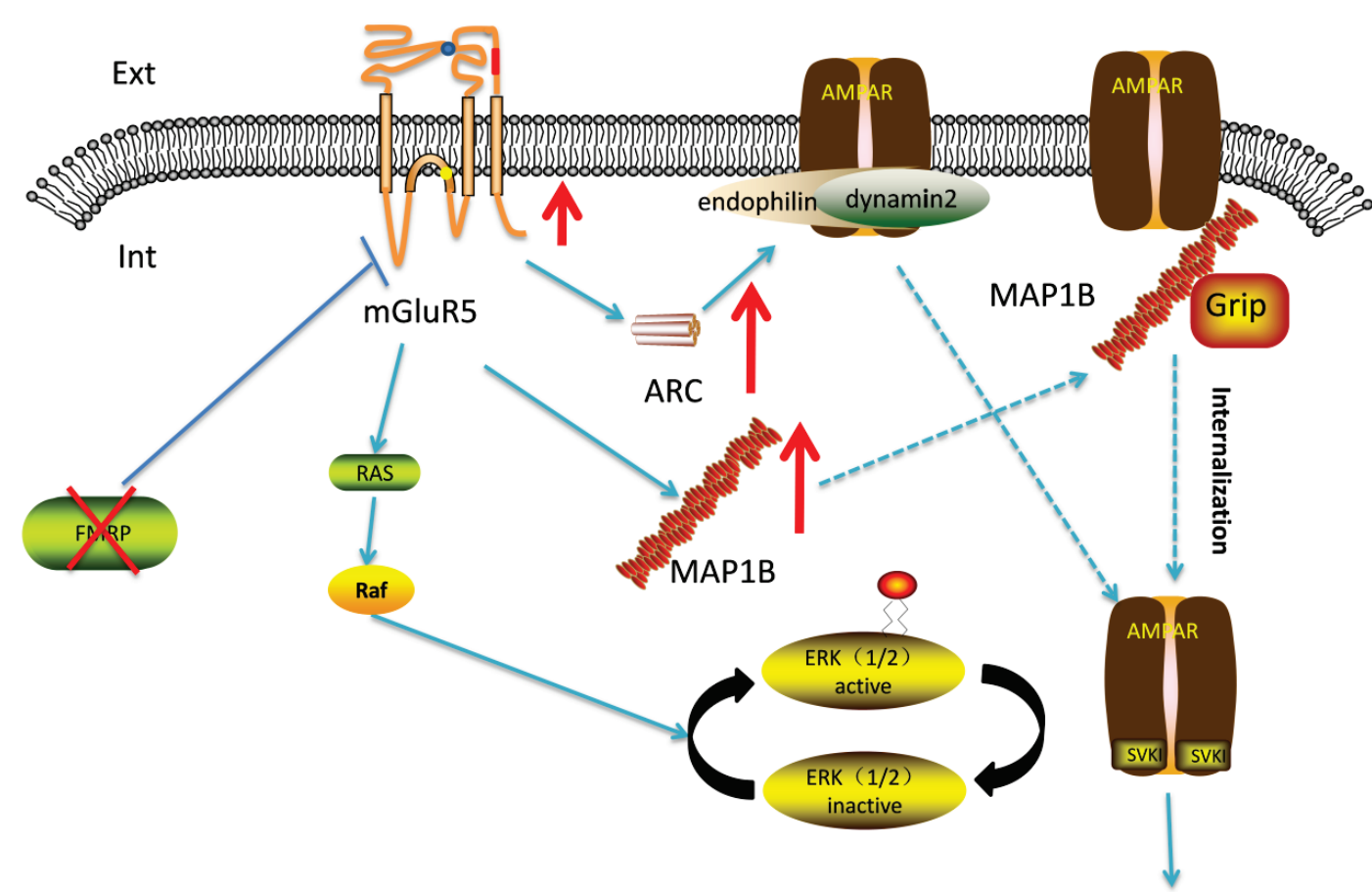

LTD

Fig. 5. The molecules termed LTD proteins that are implicated in FXS, such as Arc, MAP1B, and GRIP are basally upregulated in neuronal dendrites from $f m r 1 \mathrm{KO}$ mice, and induce the internalization of AMPAR subunits. 


\section{The alteration of AMPARs synaptic transmission and plasticity in FXS}

AMPARs mediate synaptic plasticity expression related to cognitive processes such as LTP, LTD, and homeostatic plasticity. Defective AMPAR-mediated synaptic transmission and plasticity have emerged as a common phenotype in FXS animal models (Muddashetty et al. 2007, Li et al. 2002, Darnell et al. 2013, Meredith et al. 2007, Lauterborn et al. 2007, Larson et al. 2005, Koekkoek et al. 2005). Many studies have identified synaptic plasticity deficits that involve LTP in the hippocampus ( $\mathrm{Li}$ et al. 2002, Darnell et al. 2013, Lauterborn et al. 2007, Larson et al. 2005, Wilson et al. 2007, Desai et al. 2006, Zhao et al. 2005) and other cortical regions such as the thalamic afferents to the lateral amygdala (LA) (Wang et al. 2010), and the PFC in fmr1 KO mice (Xu et al. 2005, Wang et al. 2008). FMRP deficiency in adult neural stem cells leads to reduced neuronal production and maturation, and reduced LTP in the cortex ( $\mathrm{Li}$ et al. 2002). The enhanced internalization of AMPARs or impaired synaptic delivery of GluA1 results in a selective loss of GluA1 dependent LTP (Darnell et al. 2013, Lauterborn et al. 2007, Xu et al. 2012, Wang et al. 2008, Hou et al. 2006). The second form of hippocampal altered synaptic plasticity in fmrl $\mathrm{KO}$ mice is hippocampal gp I mGluR LTD, which is triggered by the activation of gp I mGluR (Bear et al. 2004, Huber et al. 2002). Indeed, dendritic protein synthesis induced by mGluR-dependent LTD, such as MAP1b, CaMKII $\alpha$, Arc, and STEP, is elevated in slice cultures from fmrl $\mathrm{KO}$ mice and fails to show induction (Darnell et al. 2011, Waung et al. 2009, Hou et al. 2006) (Figs 4 and 5). Correspondingly, in the fmrl KO mouse, synaptic plasticity (mGluR-dependent LTD) in the cerebellum is altered (enhanced) and results in learning deficits) (Huber et al. 2006). The third form of hippocampal altered synaptic plasticity in fmrl $\mathrm{KO}$ mice is homeostatic plasticity dependent on retinoic acid (RA) (Soden et al. 2010). Synaptic activity increases synaptic plasticity potential by inducing RA synthesis, which activates postsynaptic synthesis of AMPARs in dendrites and promotes synaptic insertion of newly synthesized AMPARs. FMRP is essential for this process, and RA-dependent dendritic translation of GluA1 is impaired in fmrl KO mice (Irwin et al. 2000, Braun et al. 2000, Comery et al. 1997).

A study performed in primary hippocampal neuron cultures from $f m r l \mathrm{KO}$ mice demonstrated a delay in synapse maturation, but found no differences in miniature AMPAR-mediated currents (Braun et al. 2000). Another study in organotypic hippocampal slice cultures reported small, but detectable reductions in AMPA miniature currents in fmrl $\mathrm{KO}$ cells. The reductions were only detectable when pairs of cells, fmrl $\mathrm{KO}$ and WT controls were patched within the same culture slice (Pfeiffer et al. 2007). Taken together, these studies demonstrated that the current in AMPAR mEPSCs is changed in fmrl $\mathrm{KO}$ mice and that there is impairment in GluA1/2 signals. The impaired GluA1/2 signals in $\mathrm{fmr} 1$ $\mathrm{KO}$ mice highlights the possibility that restoration of normal GluA1-dependent synaptic plasticity may reverse prominent learning deficits associated with FXS. This possibility is further supported by the findings that 7, 8-DHF induces synapse expression of AMPA GluA1 and ameliorates cognitive and spine abnormalities in $\mathrm{fmrl}$ KO mice (Tian et al. 2015).

Given the proposed hypofunction associated with AMPARs, it has been suggested that the synthetic compounds Ampakines, which are positive allosteric modulators, may be beneficial for clinical therapeutics. Ampakines allow glutamate to have a prolonged effect on AMPARs and strengthen memory retention on multiple tasks in many different species (Lynch et al. 2006). To date, the Ampakine CX-516 has progressed into Phase II clinical trials to assess its value in treating FXS (BerryKravis et al. 2006, Danysz et al. 2002). Although the study reported no adverse side-effects associated with CX-516, the Ampakine compound relative to placebo provided little improvement in behavioral tests (BerryKravis et al. 2006).

\section{Conclusions}

Over the past two decades, efforts have been made to elucidate the molecular and cellular events that underlie synaptic dysfunction in FXS. Findings from multiple studies have implicated AMPARs dysfunction in FXS. AMPAR alterations in FXS animal models are usually manifested as changes in the expression and trafficking of receptors. Other parallel mechanisms associated with FXS include AMPAR phosphorylation/dephosphorylation, alterations in the trafficking of AMPAR mRNAs, and synthesis/degradation of the receptor proteins. These hypothesized mechanisms of FXS are supported through human genetic studies, clinical trials, postmortem brain studies, animal models, and in vitro cell cultures. 
Findings from such studies substantiate the need to monitor and manipulate synaptic AMPAR trafficking and restore AMPAR levels in order to improve cognitive function and normalize other impairments in FXS preclinical models. This new avenue of study could lead to improved understanding of the mechanisms underlying FXS and development of new clinical therapeutic applications.

\section{Conflict of Interest}

Dr. McClintock reports honoraria as teaching faculty from TMS Health Solutions. The other authors declare no conflict of interest.

\section{Acknowledgements}

This work was supported by the National Natural Science Foundation of China (grant 31271199 to Dr. Yan Zeng), and the National Natural Science Foundation of China (grant 81571095 to Dr. Yan Zeng). It was also supported by the Students' Science and Technology Innovation Fund from Wuhan University of Science and Technology (15ZRA161 to Yadie Xiang) and Students' Innovative Entrepreneurial Training Plan from Hubei Province (201510488044 to Xiangyu Li).

\section{References}

ANGGONO V, CLEM RL, HUGANIR RL: PICK1 loss of function occludes homeostatic synaptic scaling. J Neurosci 31: 2188-2196, 2011.

ANTAR LN, AFROZ R, DICTENBERG JB, CARROLL RC, BASSELL GJ: Metabotropic glutamate receptor activation regulates fragile $\mathrm{X}$ mental retardation protein and FMR1 mRNA localization differentially in dendrites and at synapses. J Neurosci 24: 2648-2655, 2004.

ANTAR LN, LI C, ZHANG H, CARROLL RC, BASSELL GJ: Local functions for FMRP in axon growth cone motility and activity-dependent regulation of filopodia and spine synapses. Mol Cell Neurosci 32: 37-48, 2006.

ASCANO M J, MUKHERJEE N, BANDARU P, MILLER JB, NUSBAUM J, CORCORAN DL: FMRP targets distinct mRNA sequence elements to regulate protein expression. Nature 493: 382-386, 2012.

BAGNI C, GREENOUGH WT: From mRNP trafficking to spine dysmorphogenesis: the roots of fragile X syndrome. Nat Rev Neurosci 6: 376-387, 2005.

BASSELL GJ, WARREN ST: Fragile X syndrome: loss of local mRNA regulation alters synaptic development and function. Neuron 60: 201-214, 2008.

BEAR MF, HUBER KM, WARREN ST: The mGluR theory of fragile X mental retardation. Trends Neurosci 27: 370-377, 2004.

BELLONE C, NICOLL RA: Rapid bidirectional switching of synaptic NMDA receptors. Neuron 55: 779-785, 2007.

BENEYTO M, MEADOR-WOODRUFF JH: Expression of transcripts encoding AMPA receptor subunits and associated postsynaptic proteins in the macaque brain. J Comp Neurol 468: 530-554, 2004.

BERRY-KRAVIS E, KRAUSE SE, BLOCK SS, GUTER S, WUU J, LEURGANS S: Effect of CX516, an AMPA-modulating compound, on cognition and behavior in fragile X syndrome: a controlled trial. $J$ Child Adolesc Psychopharmacol 16: 525-540, 2006.

BRAUN K, SEGAL M: FMRP involvement in formation of synapses among cultured hippocampal neurons. Cereb Cortex 10: 1045-1052, 2000.

BREDT DS, NICOLL RA: AMPA receptor trafficking at excitatory synapses. Neuron 40: 361-379, 2003.

CHATER TE, GODA Y: The role of AMPA receptors in postsynaptic mechanisms of synaptic plasticity. Front Cell Neurosci 8: 401, 2014.

CHUANG SC, ZHAO W, BAUCHWITZ R, BIANCHI R, WONG RK: Prolonged epileptiform discharges induced by altered group I metabotropic glutamate receptor-mediated synaptic responses in hippocampal slices of a fragile X mouse model. J Neurosci 5: 8048-8055, 2005.

COMERY TA, HARRIS JB, WILLEMS PJ, OOSTRA BA, IRWIN SA, WEILER IJ, GREENOUGHT WT: Abnormal dendritic spines in fragile X knockout mice: maturation and pruning deficits. Proc Natl Acad Sci U S A4: 5401-5404, 1997.

DANYSZ W: Positive modulators of AMPA receptors as a potential treatment for schizophrenia. Curr Opin Investig Drugs 3: 1062-1066, 2002. 
DARNELL JC, FRASER CE, MOSTOVETSKY O, DARNELL RB: Discrimination of common and unique RNA-binding activities among Fragile X mental retardation protein paralogs. Hum Mol Genet 18: 3164-3177, 2009.

DARNELL JC, KLANN E: The translation of translational control by FMRP: therapeutic targets for FXS. Nat Neurosci 16: 1530-1536, 2013.

DARNELL JC, VAN DRIESCHE SJ, ZHANG C, HUNG KY, MELE A, FRASER CE, STONE EF, CHEN C, FAK JJ, CHI SW, ET AL.: FMRP stalls ribosomal translocation on mRNAs linked to synaptic function and autism. Cell 146: 247-261, 2011.

DAVIDKOVA G, CARROLL RC: Characterization of the role of microtubule-associated protein 1B in metabotropic glutamate receptor-mediated endocytosis of AMPA receptors in hippocampus. J Neurosci 27: 13273-13278, 2007.

DAVIDS JR, HAGERMAN RJ, EILERT RE: Orthopaedic aspects of fragile-X syndrome. J Bone Joint Surg Am 72 : 889-896, 1990.

DE VRIES BB, WIEGERS AM, SMITS AP, MOHKAMSING S, DUIVENVOORDEN HJ, FRYNS JP: Mental status of females with an FMR1 gene full mutation. Am J Hum Genet 58: 1025-1032, 1996.

DENG PY, ROTMAN Z, BLUNDON JACHO Y, CUI J, CAVALLI V: FMRP regulates neurotransmitter release and synaptic information transmission by modulating action potential duration via BK channels. Neuron 77: 696-711, 2013.

DESAI NS, CASIMIRO TM, GRUBER SM, VANDERKLISH PW: Early postnatal plasticity in neocortex of Fmr1 knockout mice. J Neurophysiol 96: 1734-1745, 2006.

DIERSSEN M, RAMAKERS GJ: Dendritic pathology in mental retardation: from molecular genetics to neurobiology. Genes Brain Behav 5 (Suppl 2): 48-60, 2006.

FENG Y, ABSHER D, EBERHART DE, BROWN V, MALTER HE, WARREN ST: FMRP associates with polyribosomes as an $\mathrm{mRNP}$, and the I304N mutation of severe fragile $\mathrm{X}$ syndrome abolishes this association. Mol Cell 1: 109-118, 1997.

FREUND LS, REISS AL, ABRAMS MT: Psychiatric disorders associated with fragile $\mathrm{X}$ in the young female. Pediatrics 91: 321-329, 1993.

FU YH: Variation of the CGG repeat at the fragile $\mathrm{X}$ site results in genetic instability: resolution of the Sherman paradox. Cell 67: 1047-1058, 1991.

GARBER KB, VISOOTSAK J, WARREN ST: Fragile X syndrome. Eur J Hum Genet 16: 666-672, 2008.

GROSSMAN AW, ALDRIDGE GM, LEE KJ, ZEMAN MK, JUN CS, AZAM HS: Developmental characteristics of dendritic spines in the dentate gyrus of Fmr1 knockout mice. Brain Res 1355: 221-227, 2010.

GU Y, STORNETTA RL: Synaptic plasticity, AMPA-R trafficking, and Ras-MAPK signaling. Acta Pharmacol Sin 28: 928-936, 2007.

GUO W, ALLAN AM, ZONG R, ZHANG L, JOHNSON EB, SCHALLER EG: Ablation of Fmrp in adult neural stem cells disrupts hippocampus-dependent learning. Nat Med 17: 559-565, 2011.

GUO W, POLICH ED, SU J: Fragile X Proteins FMRP and FXR2P Control synaptic GluA1 expression and neuronal maturation via distinct mechanisms. Cell Rep 11: 1651-1666, 2015.

HAERING SC, TAPKEN D, PAHL S, HOLLMANN M: Auxiliary subunits: shepherding AMPA receptors to the plasma membrane. Membranes 4: 469-490, 2014.

HAGERMAN P: Fragile X-associated tremor/ataxia syndrome (FXTAS): pathology and mechanisms. Acta Neuropathol 126: 1-19, 2013.

HAMAD MI, MA-HÖGEMEIER ZL, RIEDEL C, CONRADS C, VEITINGER T, HABIJAN T, SCHULZ JN, KRAUSE M, WIRTH MJ, HOLLMANN M, ET AL.: Cell class-specific regulation of neocortical dendrite and spine growth by AMPA receptor splice and editing variants. Development 138: 4301-4313, 2011.

HANLEY JG: Subunit-specific trafficking mechanisms regulating the synaptic expression of Ca2+-permeable AMPA receptors. Semin Cell Dev Biol 27: 14-22, 2014.

HARLOW EG, TILL SM, RUSSELL TA, WIJETUNGE LS, KIND P, CONTRACTOR A: Critical period plasticity is disrupted in the barrel cortex of FMR1 knockout mice. Neuron 65: 385-398, 2010. 
HARRIS SW, HESSL D, GOODLINJONES B, FERRANTI J, BACALMAN, BARBATO I: Autism profiles of males with fragile X syndrome. Am J Ment Retard 113: 427-438, 2008.

HOU L, ANTION MD, HU D, SPENCER CM, PAYLOR R, KLANN E: Dynamic translational and proteasomal regulation of fragile $\mathrm{X}$ mental retardation protein controls mGluR-dependent long-term depression. Neuron 51: 441-454, 2006.

HOU Q, HUANG Y, AMATO S, SNYDER SH, HUGANIR RL, MAN HY: Regulation of AMPA receptor localization in lipid rafts. Mol Cell Neurosci 38: 213-223, 2008.

HU H, QIN Y, BOCHORISHVILI G, ZHU Y, AELST LV, ZHU JJ: Ras signaling mechanisms underlying impaired GluR1-dependent plasticity associated with fragile X syndrome. J Neurosci 28: 7847-7862, 2008.

HU Y, QU L, SCHIKORSKI T: Mean synaptic vesicle size varies among individual excitatory hippocampal synapses. Synapse 62: 953-957, 2008.

HUBER KM: The fragile X-cerebellum connection. Trends Neurosci 29: 183-185, 2006.

HUBER KM, GALLAGHER SM, WARREN ST, BEAR MF: Altered synaptic plasticity in a mouse model of fragile X mental retardation. Proc Natl Acad Sci US A 99: 7746-7750, 2002.

IRWIN SA, GALVEZ R, GREENOUGH WT: Dendritic spine structural anomalies in fragile-X mental retardation syndrome. Cereb Cortex 10: 1038-1044, 2000.

ISAAC JT, ASHBY MC, MCBAIN CJ: The role of the GluR2 subunit in AMPA receptor function and synaptic plasticity: Neuron 54: 859-871, 2007.

JIN P, ALISCH RS, WARREN ST: RNA and microRNAs in fragile X mental retardation. Nat Cell Biol 6: 1048-1053, 2004.

KEIFER J, ZHENG Z: AMPA Receptor trafficking and learning. Eur J Neurosci 32: 269-277, 2010.

KEMPER MB, HAGERMAN RJ, ALTSHUL-STARK D: Cognitive profiles of boys with the fragile X syndrome. Am J Med Genet 30: 191-200, 1988.

KESSELS HW, MALINOW R: Synaptic AMPA receptor plasticity and behavior. Neuron 61: 340-350, 2009.

KIELLAND A, BOCHORISHVILI G, CORSON J, ROSIN DL, HEGGELUND P: Activity patterns govern synapse-specific AMPA receptor trafficking between deliverable and synaptic pools. Neuron 62: 84-101, 2009.

KLEMMER P, MEREDITH RM, HOLMGREN CD, KLYCHNIKOV OI, STAHL-ZENG J, LOOS M: Proteomics, ultrastructure, and physiology of hippocampal synapses in a fragile $\mathrm{X}$ syndrome mouse model reveal presynaptic phenotype. J Biol Chem 286: 25495-25504, 2011.

KOEKKOEK SK, YAMAGUCHI K, MILOJKOVIC BA: Deletion of FMR1 in Purkinje cells enhances parallel fiber LTD, enlarges spines, and attenuates cerebellar eyelid conditioning in Fragile X syndrome. Neuron 47: 339-352, 2005.

LARSON J, JESSEN RE, KIM D, FINE AK, DU HJ: Age-dependent and selective impairment of long-term potentiation in the anterior piriform cortex of mice lacking the fragile X mental retardation protein. $J$ Neurosci 41: 9460-9469, 2005.

LAUTERBORN JC, REX CS, KRAMAR E, CHEN LY, PANDYARAJAN V, LYNCH G: Brain-derived neurotrophic factor rescues synaptic plasticity in a mouse model of fragile X syndrome. J Neurosci 27: 10685-10694, 2007.

LI J, PELLETIER MR, PEREZ VELAZQUEZ JL, CARLEN PL: Reduced cortical synaptic plasticity and GluR1 expression associated with fragile X mental retardation protein deficiency. Mol Cell Neurosci 19: 138-151, 2002.

LI Y, ZHAO X: Concise review: Fragile X proteins in stem cell maintenance and differentiation. Stem Cells 32: 1724-1733, 2014.

LIAO D, HESSLER NA, MALINOW R: Activation of postsynaptically silent synapses during pairing-induced LTP in CA1 region of hippocampal slice. Nature 375: 400-404, 1995.

LIAO L, PARK SK, XU T: Quantitative proteomic analysis of primary neurons reveals diverse changes in synaptic protein content in fmrl knockout mice. Proc Natl Acad Sci U S A 105: 15281-15286, 2008.

LIM CS, HOANG ET, VIAR KE, SCOTT MM, ZHU JJ: Pharmacological rescue of Ras signaling, GluA1-dependent synaptic plasticity, and learning deficits in a fragile X model. Genes Dev 28: 273-289, 2014.

LOESCH DZ, HUGGINS RM, HAGERMAN RJ: Phenotypic variation and FMRP levels in fragile X. Ment Retard Dev Disabil Res Rev 20: 31-41, 2004. 
LUBS HA: A marker X chromosome. Am J Hum Genet 21: 231-244, 1969.

LYNCH G, GALL CM: Ampakines and the threefold path to cognitive enhancement. Trends Neurosci 29: 554-562, 2006.

MALENKA RC: The long-term potential of LTP. Nat Rev Neurosci 11: 923-926, 2003.

MCBRIDE SM, CHOI CH, WANG Y, LIEBELT D, BRAUNSTEIN E, FERREIRO D: Pharmacological rescue of synaptic plasticity, courtship behavior, and mushroom body defects in a Drosophila model of fragile X syndrome. Neuron 45: 753-764, 2005.

MEDINA JF, MAUK MD: Computer simulation of cerebellar information processing. Nat Neurosci (3 Suppl): 1205-1211, 2000.

MEREDITH RM, HOLMGREN CD, WEIDUM M, BURNASHEV N, MANSVELDER HD: Increased threshold for spike-timing-dependent plasticity is caused by unreliable calcium signaling in mice lacking fragile $\mathrm{X}$ gene FMR1. Neuron 54: 627-638. 2007.

MIENTJES EJ, NIEUWENHUIZEN I, KIRKPATRICK L, ZU T, HOOGEVEEN-WESTERVELD M, SEVERIJNEN L: The generation of a conditional Fmr1 knock out mouse model to study Fmrp function in vivo. Neurobiol Dis 21: 549-555, 2006.

MUDDASHETTY RS, KELIC S, GROSS C, XU M, BASSELL GJ: Dysregulated metabotropic glutamate receptordependent translation of AMPA receptor and postsynaptic density-95 mRNAs at synapses in a mouse model of fragile X syndrome. J Neurosci 20: 5338-5348, 2007.

NAKAMOTO M, NALAVADI V, EPSTEIN MP, NARAYANAN U, BASSELL GJ, WARREN ST: Fragile X mental retardation protein deficiency leads to excessive mGluR5-dependent internalization of AMPA receptors. Proc Natl Acad Sci U S A 104: 15537-15542, 2007.

NEVES G, COOKE SF, BLISS TV: Synaptic plasticity, memory and the hippocampus: a neural network approach to causality. Nat Rev Neurosci 9: 65-75, 2008.

NICOLL RA, MALENKA RC: Neurobiology. Long-distance long-term depression. Nature 388: 427-428, 1997.

OBERLE I, ROUSSEAU F, HEITZ D, HANNUER A: Instability of a 550-base pair DNA segment and abnormal methylation in fragile X syndrome. Science 252: 1097-1102, 1991.

O'DONNELL WT, WARREN ST: A decade of molecular studies of fragile X syndrome. Annu Rev Neurosci 25: 315-338, 2002.

OOSTRA BA, BAKKER CE, REYNIERS E: Fmr1 knockout mice: a model to study fragile X mental retardation: The Dutch-Belgian Fragile X Consortium. Cell 78: 23-33, 1994.

PATEL AB, HAYS SA, BUREAU I, HUBER KM, GIBSON JR: A target cell-specific role for presynaptic Fmr1 in regulating glutamate release onto neocortical fast-spiking inhibitory neurons. $J$ Neurosci 33: 2593-2604, 2013.

PERESTENKO PV, HENLEY JM: Characterization of the intracellular transport of GluR1 and GluR2 alpha-amino-3hydroxy-5-methyl-4-isoxazole propionic acid receptor subunits in hippocampal neurons. J Biol Chem 278: 43525-43532, 2003.

PETRALIA RS, ESTEBAN JA, WANG YX, PARTRIDGE JG, ZHAO H, WENTHOLD RJ: Selective acquisition of AMPA receptors over postnatal development suggests a molecular basis for silent synapses. Nat Neurosci 2: 31-36, 1999.

PFEIFFER BE, HUBER KM: Fragile X mental retardation protein induces synapse loss through acute postsynaptic translational regulation. J Neurosci 27: 3120-3130, 2007.

PILPEL Y, KOLLEKER A, BERBERICH S, GINGER M, FRICK A, MIENTJES E: Synaptic ionotropic glutamate receptors and plasticity are developmentally altered in the CA1 field of Fmr1 knockout mice. $J$ Physiol 587: 787-804, 2009.

ROGERS SJ, WEHNER DE, HAGERMAN R: The behavioral phenotype in fragile X: symptoms of autism in very young children with fragile $\mathrm{X}$ syndrome, idiopathic autism, and other developmental disorders. $J$ Dev Behav Pediatr 22: 409-417, 2002.

SANTORO MR, BRAY SM, WARREN ST: Molecular mechanisms of fragile X syndrome: a twenty-year perspective. Annu Rev Pathol 7: 219-245, 2012.

SHEPHERD JD, RUMBAUGH G, WU J, CHOWDHURY S, PLATH N, KUHL D: Arc/Arg3.1 mediates homeostatic synaptic scaling of AMPA receptors. Neuron 52: 475-484, 2006. 
SHERMAN SL: Use of model systems to understand the etiology of fragile X-associated primary ovarian insufficiency (FXPOI). J Neurodev Disord 6: 1-12, 2014.

SKINNER M, HOOPER S, HATTON DD, ROBERTS J, MIRRETT P, SCHAAF J: Mapping nonverbal IQ in young boys with fragile X syndrome. Am J Med Genet A 132: 25-32, 2005.

SODEN ME, CHEN L: Fragile X: protein FMRP is required for homeostatic plasticity and regulation of synaptic strength by retinoic acid. $J$ Neurosci 30: 16910-16921, 2010.

SPENCER CM, SERYSHEVA E, YUVA-PAYLOR LA, OOSTRA BA, NELSON DL, PAYLOR R: Exaggerated behavioral phenotypes in Fmr1/Fxr2 double knockout mice reveal a functional genetic interaction between Fragile X-related proteins. Hum Mol Genet 15: 1984-1994, 2006.

SPENCER CM: Modifying behavioral phenotypes in Fmr1KO mice: genetic background differences reveal autistic-like responses. Autism Res 4: 40-56, 2011.

STELLWAGEN D, MALENKA RC: Synaptic scaling mediated by glial TNF-alpha. Nature 440: 1054-1059, 2006.

SULLIVAN SD, WELT C, SHERMAN S: FMR1 and the continuum of primary ovarian insufficiency. Semin Reprod Med 29: 299-307, 2011.

SUTCLIFFE JS, NELSON DL, ZHANG F, PIERETTI M, CASKEY CT, SAXE D, WARREN ST: DNA methylation represses FMR-1 transcription in fragile X syndrome. Hum Mol Genet 1: 397-400, 1992.

SUVRATHAN A, HOEFFER CA, WONG H, KLANN E, CHATTARJI S: Characterization and reversal of synaptic defects in the amygdala in a mouse model of fragile X syndrome. Proc Natl Acad Sci U S A 25: 11591-11596, 2010.

TIAN M, ZENG Y, HU Y, YUAN X, LIU S, LI J, LU P, SUN Y, GAO L, FU D, ET AL.: 7, 8-Dihydroxyflavone induces synapse expression of AMPA GluA1 and ameliorates cognitive and spine abnormalities in a mouse model of fragile X syndrome. Neuropharmacology 89: 43-53, 2015.

TILL SM, WIJETUNGE LS, SEIDEL VG, HARLOW E, WRIGHT AK, BAGNI C: Altered maturation of the primary somatosensory cortex in a mouse model of fragile X syndrome. Hum Mol Genet 21: 2143-2156, 2012.

TSIOURIS JA, BROWN WT: Neuropsychiatric symptoms of fragile $\mathrm{X}$ syndrome: pathophysiology and pharmacotherapy. CNS Drugs 18: 687-703, 2004.

URBANSKA M, BLAZEJCZYK M, JAWORSKI J: Molecular basis of dendritic arborization. Acta Neurobiol Exp (Wars) 68: 264-288, 2008.

VERKERK AJ, PIERETTI M, SUTCLIFFE JS, FU YH, KUHL DP, PIZZUTI A: Application of anchor-pile retaining structures to deep foundation pit of jinyu technology center. Chinese J Geotech Eng 8: 139-143, 2008.

WANG G, GILBERT J, MAN HY: AMPA Receptor trafficking in homeostatic synaptic plasticity: functional molecules and signaling cascades. Neural Plast 2012: 825364, 2012.

WANG H, KIM SS, ZHUO M: Roles of fragile X mental retardation protein in dopaminergic stimulation-induced synapse-associated protein synthesis and subsequent alpha-amino-3-hydroxyl-5-methyl-4-isoxazole-4propionate (AMPA) receptor internalization. J Biol Chem 285: 21888-21901, 2010.

WANG H, LUO M, LI C, WANG G: Propofol post-conditioning induced long-term neuroprotection and reduced internalization of AMPAR GluR2 subunit in a rat model of focal cerebral ischemia/reperfusion. $J$ Neurochem 119: 210-219, 2011.

WANG H, WU LJ, LEE F, GONG B, TOYODA H, REN M: FMRP acts as a key messenger for dopamine modulation in the forebrain. Neuron 59: 634-647, 2008.

WAUNG MW, HUBER KM: Protein translation in synaptic plasticity: mGluR-LTD, Fragile X. Curr Opin Neurobiol 19: 319-326, 2009.

WILSON BM, COX CL: Absence of metabotropic glutamate receptor-mediated plasticity in the neocortex of fragile X mice. Proc Natl Acad Sci U S A 104: 2454-2459, 2007.

WU G, SHEN Y: Gene diagnosis of fragile X syndrome. Zhonghua Fu Chan Ke Za Zhi 32: 698-700, 1997.

XIAO MY, WASLING P, HANSE E, GUSTAFSSON B: Creation of AMPA-silent synapses in the neonatal hippocampus. Nat Neurosci 7: 236-243, 2004.

XU ZH, YANG Q, FENG B, LIU SB, ZHANG N, XING JH: Group I mGluR antagonist rescues the deficit of D1-induced LTP in a mouse model of fragile X syndrome. Mol Neurodegener 7: 1-14, 2012. 
YAN QJ, RAMMAL M, TRANFAGLIA M, BAUCHWITZ RP: Suppression of two major Fragile X Syndrome mouse model phenotypes by the mGluR5 antagonist MPEP. Neuropharmacology 49: 1053-1066, 2005.

ZHANG Y, VENKITARAMANI DV, GLADDING CM, ZHANG Y, KURUP P, MOLNAR E: The tyrosine phosphatase STEP mediates AMPA receptor endocytosis after metabotropic glutamate receptor stimulation. J Neurosci 28: 10561-10566, 2008.

ZHAO MG, TOYODA H, LEE YS, WU LJ, KO SW, ZHANG XH, JIA Y: Roles of NMDA NR2B subtype receptor in prefrontal long-term potentiation and contextual fear memory. Neuron 47: 859-872, 2005. 